\title{
Creativity and Marketing
}


This is a long-overdue study of creativity and marketing for the 21st century that is packed with delights. Creativity is central to the real world of marketing, yet as technology has completely reshaped marketing activity, books on creativity have not kept up - until now! Combining theory, empirical evidence, and case studies, just a small snapshot of the imaginative, eclectic content includes clean beauty, art co-creation for luxury brands, and using artificial intelligence to design recipes and flavours for beer. I greatly enjoyed reading this book and hope that you do too. It is an excellent text for undergraduate and postgraduate students, scholars, and marketing practitioners.

Charles Dennis, Professor of Consumer Behaviour, Middlesex University. 


\section{Creativity and Marketing: The Fuel for Success}

\section{EDITED BY}

\section{ELEONORA PANTANO}

University of Bristol, UK

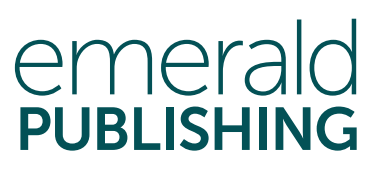

United Kingdom - North America - Japan - India - Malaysia - China 
Emerald Publishing Limited

Howard House, Wagon Lane, Bingley BD16 1WA, UK

First edition 2021

Copyright (C 2021 Emerald Publishing Limited

Reprints and permissions service

Contact: permissions@emeraldinsight.com

No part of this book may be reproduced, stored in a retrieval system, transmitted in any form or by any means electronic, mechanical, photocopying, recording or otherwise without either the prior written permission of the publisher or a licence permitting restricted copying issued in the UK by The Copyright Licensing Agency and in the USA by The Copyright Clearance centre. Any opinions expressed in the chapters are those of the authors. Whilst Emerald makes every effort to ensure the quality and accuracy of its content, Emerald makes no representation implied or otherwise, as to the chapters' suitability and application and disclaims any warranties, express or implied, to their use.

British Library Cataloguing in Publication Data

A catalogue record for this book is available from the British Library

ISBN: 978-1-80071-331-4 (Print)

ISBN: 978-1-80071-330-7 (Online)

ISBN: 978-1-80071-332-1 (Epub) 
To Vincenzo (Grillo) and Vincenzo (Forciniti) because they've always been there for me. 
This page intentionally left blank 


\section{Contents}

List of Figures ix

List of Tables $\quad x i$

Contributor Biographies xiii

List of Contributors xix

Acknowledgements $\quad x x i$

Preface xxiii

Section I Creativity in Marketing Management

Chapter 1 Creative Marketing and the Clothes Swapping Phenomenon

Claudia E. Henninger

Chapter 2 Promoting Within Sport: An Exploration of Creativity in Traditional, Extreme and Esports Contexts Luke Devereux, Francesco Raggiotto, Daniele Scarpi and Andrea Moretti

Chapter 3 Creativity, Interactive Marketing and Communication in Italian Jewellery Districts

Clara Bassano and Paolo Piciocchi

Chapter 4 Getting Creative with Sustainability Communication in the Beauty Industry: Exploring On-pack Practices and Consumers' Perceptions

Panayiota Alevizou 
Section II Creativity, Design Thinking and Innovation

Chapter 5 Design Thinking - Interactively Co-creating Innovative Products That Fit the Market

Christine Falkenreck

Chapter 6 Using Design Thinking to Drive Human-centred Innovation in Marketing

Stacy Landreth Grau

Chapter 7 Can Artificial Intelligent Systems Be Creative? A Preliminary Study in the New Product Development Process for New Drinks

Francesca Serravalle and Eleonora Pantano

Section III Creativity Challenges and Opportunities for Marketing

Chapter 8 Viral versus Virtuous - How Creative Drive for Buzz Can Also Drive Reputational Damage Raffaello Rossi and Agnes Nairn

Chapter 9 Creative Art-based Initiatives Enabling Value Co-creation in the Luxury Fashion Industry Huiru Yang, Delia Vazquez and Marta Blazquez

Chapter 10 When Fake Becomes Real: The Innovative Case of Artificial Influencers

Carsten Baumgarth, Alexandra Kirkby and Cosima Kaibel

Chapter 11 Capturing Marketing Academics' Conceptions of Creativity: Teaching Practices and Challenges in Greek Higher Education

Paschalia Patsala, Constantinos-Vasilios Priporas, Maria Michali and Irene Kamenidou 


\section{List of Figures}

Fig. 3.1. Life Cycle Model of District Relations

Fig. 3.2. The Map of the Websites of the Jewellery Districts in Relation to the Degree of Systemic Communication Achieved

Fig. 5.1. A Standard DT Process Including Iterative Loops, Suggested by HPI D-School

Fig. 5.2. Shortened DT Process 73

Fig. 5.3. Using DT to Adjust Marketing Strategy and Marketing Mix Activities

Fig. 5.4. Example of an Original DT Workshop Slide, Visualisation of Prototype, Steps H and I (Ideation Phase)

Fig. 5.5. DT Workshop: Content of Process Steps 80

Fig. 7.1. Monker's Garkel Gin by Circumstance Distillery 109

Fig. 9.1. The Working Mechanism of ABIs 136

Fig. 9.2. Value Creation Conceptualisation 141

Fig. 9.3. The Conceptual Framework for ABIs-enabled Value Co-creation

Fig. 10.1. CGII imma.gram 152

Fig. 10.2. Skin Colour of the CGIIs 154

Fig. 10.3. Engagement Rate of CGIIs 156

Fig. 11.1. Final Thematic Map with Five Themes and Nine
Sub-themes 
This page intentionally left blank 


\section{List of Tables}

Table 3.1. Evolution in Italian Gold Jewellery Exports 36

Table 3.2. Analysed Websites 41

Table 3.3. The Research Design 42

Table 5.1. Using DT to Understand Customers' Requirements 76

Table 7.1. Level of Creativity in Integration of AI in NPD Process $\quad 110$

Table 10.1. Criteria for the Description of CGIIs 153

Table 10.2. Selected Approaches to Handling Artificiality 154

Table 10.3. Evaluation of CGIIs by Brand Management 163 
This page intentionally left blank 


\section{Contributor Biographies}

Dr Panayiota Alevizou is a Lecturer in Marketing and a Co-chair of the SIG Sustainability (Academy of Marketing). The key pillars of her research are the engagement of consumers with eco labels and certifications and companies' sustainability communication strategies. She has edited and authored several books and has received the 2017 Emerald Literati Network Awards for Excellence.

Clara Bassano, PhD in Public Management, University of Salerno, is currently Associate Professor of Management at the University of Salerno, Italy. She was Visiting Researcher at IBM Almaden Research Center (Silicon Valley - California), Visiting Fellow at the Ovidius University (Romania) and Visiting Researcher at the Middlesex University of London (UK). She was awarded the IBM Faculty Award 2010. She is Italian Ambassador for International Society of Service Innovation Professionals. Her research activities include the analysis of innovation and marketing management related to the application of artificial intelligence technologies to systems. Her findings have appeared in books and international journals, for example, The International Journal of Electronic Commerce, Sustainability, Journal of Retailing and Consumer Services, INFORMS Service Science Journal, Cities and Land Use Policy.

Dr Carsten Baumgarth studied, obtained his doctorate and habilitated at the University Siegen. From 2006 to 2010, he taught as an Associate Professor at Marmara University Istanbul (Turkey). Since 2010, he has been Professor of Marketing with a focus on brand management at the Carsten Baumgarth, Hochschule für Wirtschaft und Recht Berlin. Since 2017, he has been Adjunct Professor at the Ho-Chi-Minh-City University (Vietnam). To this date, he has over 400 publications focussing on branding, B-to-B-marketing, culture marketing and empirical research. His publications appeared in journals such as the Journal of Business Research, Industrial Marketing Management, European Journal of Marketing, Journal of Marketing Communications, Journal of Brand Management, Journal of Product and Brand Management and Marketing ZFP. Furthermore, he is author of the standard book brand policy (4th edition, 2014) and of the editors work B-to-B Brand Management (2nd edition, 2018). His research has repeatedly received national and international Best Paper Awards.

Dr Marta Blazquez is a Senior Lecturer in Fashion Marketing at the University of Manchester. She was awarded a European PhD in Marketing with Cum Laude 
mention. Her research interest includes omnichannel retail, experiential marketing, in-store technology, digital branding and digital sustainability. Her research has been published in leading journals and presented in national and international conferences. She has been Visiting Researcher in the Oxford Institute of Research Management, University of Oxford, and has been Invited Lecturer on several occasions in China and Spain. She supervises a number of $\mathrm{PhD}$ and MSc students in the areas of fashion marketing, retailing and sustainability.

Luke Devereux, $\mathrm{PhD}$, is a Lecturer in Digital Marketing and Analytics at the Business School at Middlesex University, London. His current research interests are in digital marketing, corporate identity and social enterprise. He has published in Journal of Business Research and International Studies of Management and Organization.

Christine Falkenreck, PhD, University of Kassel, has been Professor of Economics and Industrial Marketing at Hof University, Germany since 2013. Her research interests cover customer relationship marketing and the implications of the Internet of Things for international B-to-B sales and marketing communication strategies. She has published in the Industrial Marketing Management journal, and other journals. She frequently co-operates with international industrial companies to work on their marketing strategies.

Stacy Landreth Grau, $\mathrm{PhD}$, is a Professor of Entrepreneurship and Innovation Practice at the Neeley School of Business and Director, IdeaFactory at Texas Christian University (TCU). She has been on the faculty since 2006 and holds a MS and PhD in Business Administration (Marketing) from Louisiana State University. She taught courses in marketing including design thinking, digital and social media marketing and marketing communications. She joined the Entrepreneurship and Innovation department at TCU to teach social entrepreneurship, design for social impact, entrepreneurial leadership and creativity and innovation. Currently, she focusses on design thinking/human centred design, where she has developed several courses and workshops at TCU for both Neeley and IdeaFactory. She has authored or co-authored more than 30 peer reviewed articles and two books. She consults with businesses, nonprofits and schools as a co-founder of HCO Lab that assists organisations to focus more on the human connections necessary for success.

Dr Claudia E. Henninger is a Senior Lecturer in Fashion Marketing Management, with a research interest in sustainability, the circular economy and more specifically collaborative consumption, in the context of the fashion industry. Her work has been published in the European Journal of Marketing, the Journal of Fashion Marketing and Management and the International Journal of Management Review, and she has edited a variety of books on sustainable fashion, including 'Sustainability in Fashion - A Cradle to Upcycle Approach'. She is further the Chair of the Academy of Marketing's SIG Sustainability. 
Cosima Kaibel studied Art and Design in Bournemouth, UK before she completed her Bachelor's degree in International Business Management at the Hochschule für Wirtschaft und Recht Berlin. She then studied Design Thinking at the HPI D-School in Potsdam and worked in various positions in branding, PR and innovation consulting. She is now working as a Research Associate at the Hochschule für Wirtschaft und Recht Berlin and is Co-founder of the Startup Dreirad.

Irene Kamenidou, $\mathrm{PhD}$, is a Professor of Marketing at the International Hellenic University, Greece. She holds a PhD in Food Marketing and has more than 10 years of working experience in the public and private sectors on agricultural and food marketing. Her work has been published in various international academic journals and conferences, such as the Journal of Business Research and International Marketing Review. Her research interests focus on agricultural and food marketing, tourism, retailing, health and social marketing. She has participated in several EU-funded projects and she served as a Dean of the Business School at Eastern Macedonia and Thrace Institute of Technology.

Alexandra Kirkby studied her undergraduate degree in German and Business at the University of Warwick in the UK and then completed her master's degree in International Marketing Management at the Hochschule für Wirtschaft und Recht Berlin, where she is now a Research Associate. She has experience in the influencer industry having worked as an Artist \& Repertoire Manager and then Sales Manager at multi-platform network Studio71 GmbH. She is now studying her doctorate degree with a focus on branding and artificial intelligence at the Hochschule für Wirtschaft und Recht Berlin and the University of Twente (The Netherlands).

Maria Michali works as a Research Assistant in the South-East European Research Centre (SEERC) based in Thessaloniki, Greece, conducting research within the context of European Commission funded projects. She holds a BA in English Language and Literature from the School of English of the Aristotle University of Thessaloniki (Greece), as well as an MA in Applied Linguistics with TESOL from the University of Sheffield International Faculty, CITY College. Her research interests include learning and teaching in HE, as well as corpus linguistics and its pedagogical applications.

Andrea Moretti is Full Professor of Marketing and Management at the Department of Economics and Statistics at the University of Udine, Italy. His current research interests are consumer behaviour, marketing strategy and marketing communications. His papers have been published in the Journal of Business Research, International Journal of Advertising, International Journal of Consumer Studies and others.

Agnes Nairn is Chair of Marketing at the School of Management, University of Bristol. Her work focusses on the intersection of marketing, regulation, policy 
and consumer rights and protection. In 2018, she acted as Special Advisor to the House of Lords Communication Committee which produced the report $U K$ advertising in a digital age and she has recently co-authored a report on Twitter gambling advertising that has been taken up by regulators and cited in policy reports. She has been invited to join over 30 international multi-stakeholder projects with public, private and third sector organisations ranging from UNICEF, UN and the Brazilian Justice Ministry to Unilever, Coca-Cola and Public Health England. Work with David Cameron's Strategy Unit led directly to the practice of child peer-to-peer marketing being banned whilst her 2007 work for National Consumer Council appears on the GCSE Home Economics curriculum.

Eleonora Pantano is Senior Lecturer (Associate Professor) of Marketing at the University of Bristol. She held PhD in 'Psychology of Programming and Artificial Intelligence' (2008), MEng in Management (2005) and PGCert in Higher Education Teaching and Supporting Learning (2016). Her findings appear in several books and textbooks, and in international peer-reviewed journals (i.e., Computers in Human Behavior, Tourism Management, Journal of Business Research, Psychology and Marketing). Her papers (more than 80) have also consistently pushed the frontiers in the area of marketing and retailing and have become highly cited by academics in the field.

Paschalia Patsala, Ph.D., is a Senior Portfolio Managerworks at the Arts and Humanities Research Council (AHRC), UK, where she is heavily involved in the development, management and delivery of a range of funding schemes, partnerships and strategic activity across the entire AHRC international portfolio. She holds a PhD in Theoretical and Applied Linguistics, an MA in Lexicography, a PGCert in Learning and Teaching in Higher Education, and a BA in English Language and Literature. Her research interests include learning and teaching in HE, second language acquisition, corpus linguistics, lexicography, and educational technologies.

Paolo Piciocchi is Full Professor of Business Management at the University of Salerno, Italy where his responsibilities included Chancellor Placement Delegate. $\mathrm{He}$ is also one of the Italian Ambassadors for International Society of Service Innovation Professionals and author of numerous works, including articles, papers, books and international conference proceedings. His fields of research include: communication crisis management, innovation and creativity in complex systems (manufacturing and cultural districts) and the viable systems approach. $\mathrm{He}$ is author of several books and articles in national and international journals, such as The International Journal of Electronic Commerce, Sustainability, Journal of Retailing and Consumer Services, INFORMS Service Science Journal and Cities.

Constantinos-Vasilios Priporas, PhD, MCIM, FEMAB, is a Senior Lecturer in Marketing at Middlesex University Business School, UK. His research interests include consumer behaviour and strategic marketing with an emphasis on retailing, tourism and food. He has published in several international academic 
journals and conferences. In addition, he has co-authored the book Technology and Innovation for Marketing (2019) and co-edited the book Market Sensing Today (2015). He is a member of several professional bodies and an editorial board member of the Journal of Customer Behavior and has acted as a guest editor, reviewer and chair in academic journals and conferences.

Dr. Francesco Raggiotto is Assistant Professor of Marketing at the Department of Economics and Statistics at the University of Udine, Italy. His current research interests are in the area of tourism management and sport management. He has published in Tourism Management, Journal of Business Research, Journal of Retailing and Consumer Services, International Journal of Advertising and others.

Raffaello Rossi is a Doctoral Candidate at the School of Management, University of Bristol. He investigates the use of gambling advertising on social media. His $\mathrm{PhD}$ research aims to inform policy-makers and protect consumers - particularly, children and young persons. His general interest lies at the interface of social media marketing, public policy and consumer protection.

Dr Daniele Scarpi is Associate Professor of marketing at the Department of Management at the University of Bologna, Italy. His current research interests are in consumer behaviour and decision-making. His papers have been published in the Journal of Retailing, Journal of Travel Research, Advertising Research, Industrial Marketing Management, Tourism Management, Journal of Business Research, Marketing Letters and others.

Francesca Serravalle held a $\mathrm{PhD}$ with Honour in Business and Management at the University of Turin (Italy) in cooperation with the Institut d'Administration des Entreprises (IAE Business School) at the University of Lyon-Magellan (France). She also held MSc in Finance and Stock Markets (2016) with a thesis on digital fundraising. Her research activities mainly relate to new technologies in retailing, with emphasis on augmented reality in an omnichannel retailing. She published in international journals such as British Food Journal and Tourism Management Perspectives. She also served as ad hoc reviewer in many marketing journals.

Dr Delia Vazquez is a Senior Lecturer in Retail Marketing at the University of Manchester. She has published over 60 academic publications in the fields of online consumer behaviour and retail marketing. She has a background in industry having worked with a major FMCG portfolio of brands. She has led 20 fashion online consumer behaviour research $\mathrm{PhD}$ projects to successful completion. Her research interests are co-creation, aesthetics, para-social relationships and online consumer behavior.

Huiru Yang is currently a PhD Student at the University of Manchester. She pursued her master's degree in the University of Manchester, where she developed a consuming passion for fashion retail studies. She has a BA in English 
Education from Soochow University in China. Her primary research interest is evaluating how aesthetics will influence the value co-creation process. She is also interested in designing innovative customer solutions in the luxury fashion retail industry. 


\section{List of Contributors}

$\begin{array}{ll}\text { Panayiota Alevizou } & \text { University of Sheffield, UK } \\ \text { Clara Bassano } & \text { University of Salerno, Italy } \\ \text { Carsten Baumgarth } & \text { Hochschule für Wirtschaft und Recht Berlin, } \\ & \text { Germany } \\ \text { Marta Blazquez } & \text { University of Manchester, UK } \\ \text { Luke Devereux } & \text { Middlesex University, UK } \\ \text { Christine Falkenreck } & \text { Hof University, Germany } \\ \text { Stacy Landreth Grau } & \text { Neeley School of Business, USA } \\ \text { Claudia E. Henninger } & \text { University of Manchester, UK } \\ \text { Cosima Kaibel } & \text { Hochschule für Wirtschaft und Recht Berlin, } \\ & \text { Germany } \\ \text { Irene Kamenidou } & \text { International Hellenic University, Greece } \\ \text { Alexandra Kirkby } & \text { Hochschule für Wirtschaft und Recht Berlin, } \\ \text { Maria Michali } & \text { Germany } \\ \text { Andrea Moretti } & \text { South-East European Research Centre, } \\ \text { Agnes Nairn } & \text { Greece } \\ \text { Eleonora Pantano } & \text { University of Udine, Italy } \\ \text { Paschalia Patsala } & \text { University of Bristol, UK } \\ \text { Paolo Piciocchi } & \text { University of Bristol, UK } \\ \text { Constantinos-Vasilios Priporas } & \text { Arts and Humanies Research Council, UK } \\ \text { Francesco Raggiotto } & \text { University of Salerno, Italy } \\ \text { Raffaello Rossi } & \text { Middlesex University London, UK } \\ \text { Daniele Scarpi } & \text { University of Udine, Italy, } \\ \text { Francesca Serravalle } & \text { University of Bristol, UK } \\ \text { Delia Vazquez } & \text { University of Bologna, Italy, } \\ \text { Huiru Yang } & \text { University of Turin, Italy } \\ & \text { University of Manchester, UK } \\ \text { University of Manchester, UK }\end{array}$


This page intentionally left blank 


\section{Acknowledgements}

The first big thanks goes to the authors and contributors of this book. Their effort, patience and encouragement resulted in the pages you are actually reading. Thank you for your trust in this project and helping me to finalise it.

However, this book couldn't be possible without Niall Kennedy (Emerald Publishing), who supported and encouraged the idea since the very first moment. I couldn't do anything without his enthusiasm in this project.

I want to thank Matteo Napolitan for his encouragement in developing this book, and for all his time spent helping me find an eye-catching and appealing title. 
This page intentionally left blank 


\section{Preface}

To date, marketing is about constantly innovating to deliver successful strategies and provide new customer solutions (Grewal, Noble, Roggeveen, \& Nordfält, 2020; Inman \& Nikolova, 2017; Pantano, Priporas, \& Stylos, 2018; Pantano \& Vannucci, 2019). The ability of managing new and creative approaches and appraising the relative role and value in the marketing development would secure the company's profitability, resulting in the longevity of the company and its brands (Mazerant, Willemsen, Neijens, \& van Noort, 2021; Meesuptong, Jhudra-Indra, \& Raksong, 2014; Slater, Hult, \& Olson, 2010). However, it goes beyond the development and marketing of new products. Thus, also marketing discipline requires new visions, artistic talents, communications strategies, and so on.

In spite of much discussion about creativity and innovation (Beverland, Micheli, \& Farrelly, 2016; Christensen, Noeskov, Frederiksen, \& Scholderer, 2017; Coelho, Augusto, \& Lages, 2011; Hemonnet-Goujot, Manceau, \& AbecassisMoedas, 2019; Merlo, Bell, Mnguc, \& Whitwell, 2006; Reinartz \& Saffert, 2013; Titus, 2018), few marketers still demonstrate a remarkable ability to respond creatively and cope with the marketing uncertainties. For this reason, there is a need for a strong piece of work collecting and synthetising the actual fragmented contributions, from the creativity in strategic marketing planning and marketing mix, to the creativity in store design and consumers' salesperson relationships, from the creativity in the brand management and communication, to the creativity of artificial intelligence in new product development.

The aim of this book is to combine these contributions in a way that is accessible for academic researchers, students who want to understand creativity as part of their expertise in marketing (including branding and communication, retailing and store design and new product development), and for practitioners who are experiencing the need of new creative approaches to the marketing strategies. This book is designed to strengthen the overall understanding of the creative opportunities in marketing. In particular, it encourages readers to adopt futurefacing, creative approach to marketing management.

The book will consist of three sections: (1) Creativity in marketing management, (2) Creativity, design thinking and innovation, and (3) Creativity challenges and opportunities for marketing. Chapters included in the first section investigate creative marketing strategies and the fundamental role of creativity in communication strategies and planning, with recent and relevant supporting case studies. Chapters included in the second section mainly investigate design thinking to 
develop new products able to better meet market expectation, and to innovate in marketing. Chapters included in the third section investigate the actual challenges for marketing and the opportunities, from the risk of creative messages on brand reputation to the successful management of virtual (fake) influencers, to guide scholars on teaching creativity to marketing students.

Thus, this book provides a strong collection of theories, empirical evidence, and case study applications synthesising the emerging research on the creativity for marketing management in an accessible way. Seeking to understand how marketers might take advantage of creativity principles, this book proposes empirical and theoretical contributions, and case studies that further offer new and provocative solutions. Enjoy your reading!

\section{References}

Beverland, M. B., Micheli, P., \& Farrelly, F. J. (2016). Resourceful sensemaking: Overcoming barriers between marketing and design in NPD. Journal of Product Innovation Management, 33(5), 628-648.

Christensen, K., Noeskov, S., Frederiksen, L., \& Scholderer, J. (2017). In search of new product ideas: Identifying ideas in online communities by machine learning and text mining. Creativity and Innovation Management, 26(1), 17-30.

Coelho, F., Augusto, M., \& Lages, L. F. (2011). Contextual factors and the creativity of frontline employees: The mediating effects of role stress and intrinsic motivation. Journal of Retailing, 87(1), 31-45.

Grewal, D., Noble, S. M., Roggeveen, A. L., \& Nordfält, J. (2020). The future of in-store technology. Journal of the Academy of Marketing Science, 48, 96-113.

Hemonnet-Goujot, A., Manceau, D., \& Abecassis-Moedas, C. (2019). Drivers and pathways of NPD success in the marketing-external design relationship. Journal of Product Innovation Management, 36(2), 196-223.

Inman, J. J., \& Nikolova, H. (2017). Shopper-facing retail technology: A retailer adoption decision framework incorporating shopper attitudes and privacy concerns. Journal of Retailing, 93(1), 7-28.

Mazerant, K., Willemsen, L. M., Neijens, P. C., \& van Noort, G. (2021). Spot-on creativity: Creativity biases and their differential effects on consumer responses in (non-)realtime marketing. Journal of Interactive Marketing, 53, 15-31.

Meesuptong, J., Jhudra-Indra, P., \& Raksong, S. (2014). Strategic marketing creativity and marketing profitability: A conceptual model. International Journal of Business Research, 14(4), 7-26.

Merlo, O., Bell, S. J., Mnguc, B., \& Whitwell, G. J. (2006). Social capital, customer service orientation and creativity in retail stores. Journal of Business Research, 59, $1214-1221$.

Pantano, E., Priporas, C. V., \& Stylos, N. (2018). Knowledge push curve (KPC) in retailing: Evidence from patented innovations analysis affecting retailers' competitiveness. Journal of Retailing and Consumer Service, 44, 150-160.

Pantano, E., \& Vannucci, V. (2019). Who is innovating? An evaluation of the extent to which retailers are meeting the technology challenge. Journal of Retailing and Consumer Services, 49, 297-304.

Reinartz, W., \& Saffert, P. (2013). Creativity in advertising: When it works and when it doesn't. Harvard Business Review, 6, 1-12. 
Slater, S. F., Hult, G. T. M., \& Olson, E. M. (2019). Factors influencing the relative importance of marketing strategy creativity and marketing strategy implementation effectiveness. Industrial Marketing Management, 39(4), 551-559.

Titus, P. A. (2018). Exploring creative marketing thoughts: Divergent ideation process and outcomes. Psychology and Marketing, 35, 237-248. 
This page intentionally left blank 
Section I

Creativity in Marketing Management 
This page intentionally left blank 


\title{
Chapter 1
}

\section{Creative Marketing and the Clothes Swapping Phenomenon}

\author{
Claudia E. Henninger
}

\begin{abstract}
Swapping as part of collaborative consumption is not a new phenomenon per se, but might gain increased importance after the recent COVID-19 pandemic that has seen a shift in consumer attitudes, consumption, and disposal behaviour. Swapping as one form of collaborative consumption, however, is currently neither mainstream nor target towards the general population, but rather a niche population (secondhand consumers). With sustainable issues (environmental, economic, and social) remaining a key concern, and consumers seeking to dispose of their garments, swapping might become an increasingly attractive alternative, yet currently it may not be communicated as such. This chapter explores the potential of creative marketing communications to enhance the uptake of swapping in order to overcome a key challenge in the industry: fashion waste.
\end{abstract}

Keywords: Collaborative consumption; swapping; fashion Industry; creative marketing; sustainability communications; challenges

\section{Learning Outcomes}

- To gain a better understanding of the fashion industry during the COVID-19 pandemic which magnified sustainability issues it is facing.

- To investigate current issues in the fashion industry.

- To define and critically evaluate collaborative consumption and swapping practices.

- To explore what type of creative marketing swapping events utilise and how these could be enhanced further. 


\section{Introduction}

This chapter provides an insight into collaborative consumption in the fashion industry (here swapping practices), thereby centring on creative marketing, which, ideally, enhances the meaningful novelty of an item and thus, moves away from competing solely on price (Andrews \& Smith, 1996; Fillis, 2002; Fillis \& McAuley, 2000). Fillis and McAuley (2000, p. 8) point out that 'creativity can be messy, unexpected, a mystery, or merely frustrating', yet for marketers it can also be very rewarding, as it provides an opportunity to look outside the figurative box and focus on interrelated aspects. To explain, swapping, the exchange of idle capacity without paying an access fee (Henninger et al., 2020), could be seen as the combination of secondhand fashion and 'retailing', yet due to its lack of a monetary exchange, its association with sustainability and the sharing economy, meaning can be changed from being solely transactional to becoming emotional an aspect that is looked at within this chapter.

This chapter puts an emphasis on events that have dominated the majority of 2020: the COVID-19 pandemic. Although it could be suggested that this pandemic is (hopefully) a one-off event and thus, may be dated in relevance, it is argued that COVID-19, is just one in many events that have impacted the fashion industry and magnified issues surrounding sustainability (e.g. Blazquez, Henninger, Alexander, \& Franquesa, 2020; Brydges \& Hanlon, 2020; Henninger, Alevizou, \& Oates, 2016). To explain, sustainability issues have been discussed since the 1960s, when people became more conscious of the impact their consumption practices have on the natural environment (e.g. Brown, 2011; Peattie, 1995). In the 1980s and early 1990s, media attention centred on labour law issues, which re-surfaced with the collapse of Rana Plaza, a factory accident, in which thousands lost their lives (Business of a Better World, 2012; Parveen, 2014a, 2014b). Moreover, Channel 4's (2010) Dispatches programme has reported on 'fashion's dirty secret', thereby uncovering 'shocking' working conditions in fashion companies in the UK. Thus, it may not be surprising that there has been increase in academic publications focussing on modern slavery and its legislation in the fashion industry (e.g. Benstead, Hendry, \& Stevenson, 2019).

Thus, COVID-19 in this chapter is used to illustrate challenges the fashion industry is facing and that have been magnified as a result of the pandemic, yet it is argued that it remains relevant for the future, as the issues highlighted remain and need to be addressed in order to create a more sustainable future. Creativity marketing is one solution that can enable organisations to communicate with their current and potential customer base and create a relationship bond that has the power to facilitate more sustainable consumption, as will be outlined in the chapter.

\section{The Fashion Industry Pre- and Post-COVID-19}

The twenty-first century was predominantly concerned with creating a more sustainable future, with the United Nations (UN, 2020) having moved 'sustainability' from a simple buzzword to becoming a top global priority. Sustainability's 
most iconic definition was published by the Brundtland Commission (WCED, 1987) as focussing on the current generation's needs without compromising those of future ones, thereby centring on social, environmental, and economic aspects and its related issues (Athwal, Wells, Carrigan, \& Henninger, 2019; Henninger et al., 2016). Until quite recently, media outlets covered Greta Thunberg's call for climate action (Carrington, 2019) and the various events organised by the Extinction Rebellion (2020), yet times have changed. With the COVID-19 outbreak, sustainability has arguably taken a backseat, with fashion retailers currently fighting for survival, and thus, potentially spending less on sustainability measures as originally anticipated (Berg, Haug, Hedrich, \& Magnus, 2020; Brown, 2020; Orlova, 2020).

Pre-COVID-19 the fashion industry could best be described as a thriving sector, being the third largest manufacturing industry, only overtaken by the automotive and technology sector, and estimated to be worth US\$1.4 trillion in 2018 (Berg et al., 2020; Lissaman, 2018). Growth rates in 2019 were predicted to be between $3.5 \%$ and $4.5 \%$, and thus, seen to continuously increase (Danziger, 2019). The economic worth of the industry and the growth rates highlights two key aspects: first, fashion concerns every single person, as it provides a basic commodity (WRAP, 2020a) and is more than simply a trend. Fashion in the sense of garments, showcases our personality and belonging to social groupings (e.g. hipster, punk, and goth), it highlights our desire to be unique and creative, as well as our lifestyle. As such, fashion visualises who we are or who we want to be (e.g. Myzelev, 2013; Powell \& Gilbert, 2009), which can be enhanced through creative marketing, by focussing on meaning (Mkhize \& Ellis, 2020). Second, the fashion industry, as alluded to, is a key employer, as manufacturing fashion is highly labour intensive and supply chains are long and complex spanning often across the globe (Henninger, Alevizou, Oates, \& Cheng, 2015, chapter 6). Yet, the economic worth and the industry's glamour, enhanced by catwalk shows and TV series, for example, Top Model, come at an ethical and environmental cost, such as labour law violations, modern-day slavery, and waste, with garments being wrongfully disposed of in landfill (e.g. Environmental Audit Committee, 2019; Henninger et al., 2016; McFall-Johnsen, 2020; UN, 2019). The latter aspect can be linked to the Environmental Audit Committee's (2019) Fixing Fashion Report, which highlights that the current consumption and production patterns (takemake-use-dispose) are leading to a 'throwaway culture', hyper consumption practices, and waste problems in the UK and other countries.

Enhanced by the emergence of the fast fashion (take-make-use-dispose) phenomenon, clothing production has doubled between 2000 and 2015 (WRAP, 2020a), with companies increasingly competing on price as opposed to meaningful novelty (creative marketing) (Andrews \& Smith, 1996; Blazquez et al., 2020). The cheap prices in retail stores enhance the consumers' 'fashion appetite' (Sharma \& Hall, 2010), which has environmental costs in that more raw materials and finishings are needed, and $\mathrm{CO}_{2}$ emission increased as products are delivered to the end-consumer, as well as social costs, with manufactures feeling the need to cut corners (e.g. safety measures and wages) in order to stay competitive (Blazquez et al., 2020; Henninger, Alevizou, Goworek, \& Ryding, 2017; Henninger et al., 
2016; Skov, 2008). To explain, the increased pace of fashion consumption and the pressure to produce items that are 'cheap and cheerful' can have devastating consequences, as witnessed in the Rana Plaza incident in 2013 that saw thousands of garment workers lose their lives (Burke, 2013; Parveen, 2014a, 2014b; WRAP, 2020a).

The year 2020 and the COVID-19 pandemic brings forward further challenges as the fashion industry will be 'faced with 27 to 30 percent contraction in global revenues' (Berg et al., 2020, p. 5), and is 'currently focused on crisis management and contingency planning' (Berg et al., 2020). Various fashion retailers and wellknown department stores had to go into administration or reduce their physical stores in an attempt to stay afloat, which had and still has consequences across the supply chain (Vogue, 2020). Jobs in the retail sector, as well as along the supply chain, are lost due to current stock that remains unsold, and orders being cancelled (Vogue, 2020). Whilst the post-COVID-19 world accentuates social issues in the fashion industry, environmental issues have, even for just a short period, improved, as the standstill of manufacturing sites has meant reduced pollution, in form of $\mathrm{CO}_{2}$ emission, and consumers becoming increasingly conscious of the impact their purchases have on the natural and social environment (Berg et al., 2020; Edited, 2020; WRAP, 2020b).

Thus, we are currently at the proverbial crossroads, in that we can try to go back to the way things have been pre-COVID-19, or we take the opportunity and foster change by creating a new 'normal', thereby refocussing on the 'oxygen' of marketing: creativity (Geoghegan, 2020). This chapter explores the following research questions:

(1) Whether and how organisations are currently utilising creative marketing to promote their swapping events.

(2) How could creative marketing be used to overcome perceived risk?

\section{New Opportunity - Swapping and Changing Consumer Attitudes}

\subsection{Collaborative Consumption and Swapping}

As aforementioned, waste in the fashion industry is a key issue as it can occur as pre- and post-consumer waste (Philip, Ozanne, \& Ballantine, 2019; Weber, Lynes, \& Young, 2017). This chapter focusses on the latter (post-consumer waste) and the UK context, where the average consumer disposes of $30 \mathrm{~kg}$ of garments and textiles annually per capita (WRAP, 2012, 2020a). Fast fashion has enabled any individual to access garments, which on the one hand increased consumption, and on the other hand the creation of waste, as the cheap price tags seem to justify a decline in utilisation (WRAP, 2020b). Over a 15-year period between 2000 and 2015 , garments have been worn less, with $20 \%$ of these discarded items ending up in landfill, where they may sit for over 200 years to decompose, depending on the material (Close the Loop, 2020; Ellen McArthur Foundation (EMF), 2017). 
Pre-COVID-19 sustainability had taken centre stage, with fashion organisations actively trying to incorporate measures to counteract social and environmental issues. The industry has seen dramatic changes, with the emergence of the circular economy, that moves away from the linear process of take-make-use-dispose, to closing the loop, by reutilising 'waste' (Henninger et al., 2020; Henninger, Jones, Boardman, \& McCormick, 2018; McKinsey, 2019). Currently the annual worth of pre-maturely disposed garments globally is US\$500 million (EMF, 2017), thus it may not be surprising that new business models have emerged that are often described as 'disruptive', and capitalise on these 'waste' materials and/or idle capacities (Armstrong, Niinimäki, Kujala, Karell, \& Lang, 2015; Henninger, Bürklin, \& Niinimäki, 2019; Henninger et al., 2018; Mukendi \& Henninger, 2020). The most prominent examples of disruptive innovations in the fashion industry are Rent the Runway, a rental service that allows consumers access to garments for a specified timeframe in return for a fee and without transferring ownership, and Depop, a re-commerce platform that facilitates the selling and purchasing of mainly used items, thereby transferring ownership (Battle, Ryding, \& Henninger, 2018, chapter 3; Hu, Henninger, Boardman, \& Ryding, 2018, chapter 3; WRAP, 2020a). More recently, swap shops have emerged and although swapping is not new per se, but rather has been in existence as long as mankind (Belk, 2014), it not only remains a niche market, but also lacks investigations from a marketing communications perspective (Henninger et al., 2019). Swapping falls within the remit of collaborative consumption and is seen to be a more environmentally friendly alternative, as 'waste' materials are re-looped and garments' useful lives are extended, without any monetary transactions (Botsman \& Rogers, 2010; Iran \& Schrader, 2017; Lang \& Armstrong, 2018).

Collaborative consumption in simple terms implies exchanging goods and/or services (e.g. Botsman \& Rogers, 2010). The exchange can be between individuals that are familiar with each other (e.g. family and friends), referred to as sharingin, or between strangers (sharing-out) (Belk, 2014). The latter has been enabled through technologies, and more prominently social media, which allows people to connect without any physical boundaries, thereby overcoming time/space constraints (Park \& Armstrong, 2017). The concept of collaborative consumption has been discussed as early as the 1970s, with key contexts including the automotive and tourism industry, with only more recent work focussing on the fashion context (Armstrong et al., 2015; Bardhi \& Eckhardt, 2012; Botsman \& Rogers, 2010; Lang \& Armstrong, 2018; Tussyadiah \& Pesonen, 2016). Even though there is a trajectory of collaborative consumption research, there is no consensus on what it entails (Henninger et al., 2019; Iran \& Schrader, 2017). Felson and Spaeth (1978) indicate collaborative consumption includes any activity that brings people together and 'collectively' consume a good or service. This, however, has been criticised as being too broad, as having coffee in a café could then also be seen as collaborative consumption. Botsman and Rogers (2010) narrowed down the definition to include 'traditional sharing, bartering, lending, trading, renting, gifting, and swapping' (p. xv). Although this provides a good baseline, there are still some challenges with this definition, seeing as there are different modes of acquisition and ownership (re-distribution, non-ownership, and permanent transfer) 
involved. Whilst providing a clear-cut definition is beyond the scope of this chapter, understanding the challenges associated with it are key, as these are mirrored in the communication strategies used to promote collaborative events, more specifically swap shops, which is discussed later on in this chapter. Here, in line with previous research (Belk, 2014; Henninger et al., 2019; Iran \& Schrader, 2017), swapping is defined as an exchange that can happen between individuals that either know each other or are strangers (online or offline), thereby re-distributing the ownership of a swapped garment, without any monetary exchange.

Collaborative consumption, including swapping, has been described as more environmentally friendly business models, seeing as they are utilising 'waste' and idle capacities, by re-looping these back into the economy, and thus extending their useful life (e.g. Philip et al., 2019; WRAP, 2020a). This aspect might be even more important in the post-COVID-19 world, in that two in every five people in the UK have had a clear-out during the lockdown months, thereby, on average, 'disposing' of 11 items (18 if accessories, such as shoes, bags, and jewellery, are included) (WRAP, 2020b). Although a majority of people surveyed by WRAP (2020b) indicate that they prefer to donate unwanted garments to charities and might keep these items until charities have re-opened, $20 \%$ of these items have already ended up in landfill. It is also noteworthy to highlight that the disposable options mentioned in the survey did not explicitly mention swapping. A reason that could be provided here is the fact that swap shops can be stigmatised as being too 'alternative' or 'hipster' and thus, exclude individuals who do not associate with these social groupings.

\subsection{Consumer Attitudes, Swapping, and Creative Marketing}

One positive outcome of the recent pandemic has been the change in consumer attitudes, in that consumers are posing more questions and consider the impact their purchases have on the social and natural environment, with Orlova (2020) pointing out that we can anticipate 'a shift in the consumer mindset' that is expected to accelerate even further post-COVID-19. Similarly, WRAP (2020a) insinuates that consumers, who have been classified to love shopping and seen to be value and trend driven, are increasingly interested in alternative fashion models (e.g. renting, swapping, and re-commerce). This could provide an opportunity for swap shops (here also referred to as swapping events) to become a more popular opportunity to 'dispose' of garments, whilst at the same time refreshing one's wardrobe. Although consumer attitudes are changing, the uptake of swapping events may not, which could be in line with barriers that have previously been identified (Armstrong et al., 2015; Battle et al., 2018; Becker-Leifhold \& Iran, 2018; Henninger et al., 2019; Lang \& Zhang, 2018; Pedersen \& Netter, 2015), such as the quality of garments that are being brought to swaps, hygiene aspects, availability of sizes, infrastructure (accessibility and availability of swaps), and status. Some of these barriers to utilising swapping events could be overcome through creative marketing and effective communication strategies, which is explored in the following section. 